\title{
High court sanctions law edging US toward universal health coverage
}

$\mathrm{T}$ he massive law pushing the United States toward universal health coverage won Supreme Court validation on June 28 in a decision that advances the most ambitious reshaping of American social policy in generations.

The court's historic 5-4 ruling handed President Barack Obama a stunning election-year victory in upholding the Affordable Care Act (www.supremecourt.gov/opinions/11pdf /11-393c3a2.pdf). The court's conservative chief justice, John Roberts, sided with the court's liberal minority in declaring that the law, and its cornerstone requirement that Americans have health insurance, can go forward.

In escaping a perilous legal cloud, the 2010 law now becomes prime fodder in the campaign for the November presidential and congressional elections. Republicans have sworn to try to repeal the law the only way left to them, through Obama's defeat.

"Whatever the politics," Obama asserted afterward, "today's decision was a victory for people all over this country whose lives will be more secure because of this law and the Supreme Court's decision to uphold it."

He said the justices "reaffirmed a fundamental principle: that here in America, in the wealthiest nation on Earth, no illness or accident should lead to any family's financial ruin."

At its heart the law aims to extend coverage to more than 30 million uninsured and prohibit discriminatory practices by insurers. No longer will they be able to deny or drop coverage to sick people, charge exorbitant rates to the elderly or chronically ill, or impose lifetime limits on benefits. A range of free preventive services, checkups and mammograms among them, must be provided. Poorer Americans and many of middle-income will get subsidies to make premiums more affordable.

Through subsidies and taxation, the



US President Barack Obama said the Supreme Court's decision "reaffirmed a fundamental principle: that here in America, in the wealthiest nation on Earth, no illness or accident should lead to any family's financial ruin."

law builds on the nation's existing insurance system, which is anchored by job-based private plans cost-shared by employers and employees. It steers well clear of a single-payer system like Canada's.

Even so, it constitutes a major expansion of federal authority in health care and, to Republicans, a heavyhanded intrusion on personal freedoms.

Mitt Romney, Obama's Republican presidential rival, drew the political battle lines after the court's decision.

"This is a time of choice for the American people," he said. "Our mission is clear. If we want to get rid of Obamacare, we're going to have to replace President Obama."

"My mission is to make sure we do exactly that - that we return to the American people the privilege they've always had to live their lives in the way they feel most appropriate."

Obama's success in court was not complete. Justices ruled that the government cannot cut states off from federal money for Medicaid, the federal-state insurance program for the poor and dis- abled, if they refuse to go along with a major expansion of the program. For the moment, that leaves Washington with a carrot - billions offered to the states for the Medicaid expansion - but no stick if they want to pass on it.

Given the US Constitution's brakes on federal powers, not to mention the high court's slim conservative majority, plenty of legal experts thought the law was likely to run into messy roadblocks if not be uprooted outright. For courtwatchers, seeing Roberts side with the liberals was a jaw-dropper.

Once it became known that Roberts would be the justice writing the decision, "most assumed it was a lead-pipe cinch for an opinion striking down the individual mandate," says Jonathon Turley, a professor of public interest law at George Washington University in Washington, DC.

For states-rights advocates, he says, "this is a Brutus moment for John Roberts."

The central issue was whether Washington can require people to obtain insurance and penalize them if they don't. 
Without that individual mandate, the law's carefully constructed provisions were bound to poof like pierced balloons. Only by bringing nearly every American into the paying insurance system could the law's reforms take place without sending budget deficits and insurance costs through the roof.

The court upheld the mandate with thread-the-needle legal reasoning best understood by deep-in-the-weeds constitutional experts.

Roberts said it is, in fact, unconstitutional for the federal government to require people to get health insurance. But he said the government does have legitimate power to tax people who don't get it.

In essence, the court preserved the mandate by deciding to regard the noncompliance penalty as a tax, not a fine, and therefore something that falls under the broad powers of taxation afforded to Congress.

That was the key to getting the law out of months of legal limbo. And it was a minor consolation prize for Romney. $\mathrm{He}$ can now brand Obama as a tax raiser with some validation from the court.

The law remains unpopular on balance, with few of its presumed benefits seen by Americans so far.

One early provision, requiring insurers to let adult children stay on their parents' insurance plans until they turn 26 , has been a clear hit, drawing millions more young people into the insurance pool. But the major reforms don't take effect until 2014.
Turley says it's not clear Obama will score political gain from the ruling, with so many Americans suspicious of the law. "That's not exactly the audience you want for a victory lap."

But Democrats hope a strong constituency will grow for the reforms as they become more embedded in American life.

Medicare, the government-run insurance program for the elderly, and Medicaid took effect in 1965 in the last landmark expansion of the health care safety net.

Opposition was fierce back then, but once the benefits kicked in, all that fuss melted away. - Cal Woodward, Washington, DC

CMAJ 2012. DOI:10.1503/cmaj.109-4251 